НАУКОВИй ВІСНИК

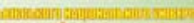

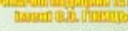

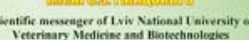

7

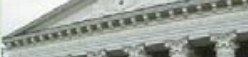

TIIIII

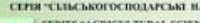
Toм 21 № 90

2019
Науковий вісник Дьвівського національного університету ветеринарної медицини та біотехнологій імені С.3. Гжицького.

Серія: Сільськогосподарські науки

Scientific Messenger of Lviv National University of Veterinary Medicine and Biotechnologies.

Series: Agricultural sciences

ISSN 2519-2698 print

https://nvlvet.com.ua/index.php/agriculture

doi: $10.32718 /$ nvlvet-a9002

\title{
Californian worms biomass growth and its zinc accumulation under different concentrations of the metal in the nutrient medium
}

\author{
S.V. Merzlov, Y.O. Mashkin, P.M. Karkach, O.I. Sobolev, O.I. Rozputnii, A.V. Kharchenko \\ Bila Tserkva National Agrarian University, Bila Tserkva, Ukraine
}

Article info

Received 22.01.2019

Received in revised form 21.02 .2019

Accepted 22.02.2019

Bila Tserkva National Agrarian University, Soborna ploshcha 8/1 Bila Tserkva, 09100, Ukraine. Tel.: +38-098-240-63-08 E-mail: yura-mashkin@ukr.net

Merzlov, S.V., Mashkin, Y.O., Karkach, P.M., Sobolev, O.I., Rozputnii, O.I., \& Kharchenko, A.V. (2019). Californian worms biomass growth and its zinc accumulation under different concentrations of the metal in the nutrient medium. Scientific Messenger of Lviv National University of Veterinary Medicine and Biotechnologies. Series: Agricultural sciences, 21(90), 9-13. doi: 10.32718/nvlvet-a9002

The ability of worms to accumulate biotic metals in their body creates the preconditions for obtaining a protein-mineral supplement containing metals in the organic compounds. Experimental studies on the worms reproduction, their mass increase and zinc organic forms accumulation in their body, depending on the content of this metal in the nutrient medium were carried out. Zinc content in the nutrient medium for worms was regulated by adding various doses of this metal salt ( $\mathrm{ZnSO} \cdot$ - 7H2O). Worms were grown for 110 days on a nutrient medium with a different content of zinc. It has been established that adding Zinc at a dose of $160 \mathrm{mg} / \mathrm{kg}$ of nutrient medium provides increase in the worms number and weight by 1.5-1.9 and 1.55-1.96 times, respectively, as compared to the worms grown on a nutrient medium without zinc addition. The negative impact of zinc at a dose of $640 \mathrm{mg} / \mathrm{kg}$ of nutrient medium on the worms mass increase was established. Vermiculture mass was $12.9 \%$ lower than the control under high dose of the metal. Additional application of zinc at doses of $40 \mathrm{mg} / \mathrm{kg}, 80,160,320$ and $640 \mathrm{mg} / \mathrm{kg}$ in growing worms on a nutrient medium provided increase in the content of this element in vermiculture dry mass, respectively, by $20.4 \%, 31.7,50.0 \%$ or by 2.7 and 3.0 times.

Key words: Zinc, red Californian worms hybrid, worms number, worms mass, vermiculture, metal accumulation

\section{Introduction}

Manure from various species of animals, peat, sawdust, hardwood, straw, cardboard, paper, tree leaves, fruits and vegetables waste products, waste of meatpacking plants, fish production, organic urban wastewater, distillery waste, sugar and brewer production, as well as riboxin, tetracycline and penicillin production mycelium is the nutrient medium for the red Californian worms hybrid (Eisenia fetida) (Melnyk, 1991; Feruchchi, 1992; Pernak, 1995; Sulzberger, 1998).

In the non-waste utilization of organic residues, red Californian worms hybrid increases its biomass, which is an adequate protein-vitamin-mineral feed supplement to the diet of farm animals, fish and poultry (Das \& Dach, 1989; 1990; Mason et al., 1992; Kostecka \& Pączka, 2006).

Worms dry matter contain up to $65.0 \%$ of protein, up to $11.0 \%$ of lipids, of which a large proportion is represented by phospholipids. Worms body contain Ferrum 680-1070 mg/kg, Magnesium - 660-842 mg/kg, Zinc
$72-80 \mathrm{mg} / \mathrm{kg}$, Cuprum - 7-8 $\mathrm{mg} / \mathrm{kg}$ and Cobalt $1.5-$ $2.5 \mathrm{mg} / \mathrm{kg}$ of dry matter.

In addition, worm biomass extract is used in hepatocarcinogenesis and eye burns treatment. Ointments and tinctures made from worm tissues are used to treat bronchitis, asthma, postpartum weakness, smallpox, jaundice and rheumatism (Kholodova et al., 1992; Kholodova et al., 1994; Hasanuzzaman et al., 2010).

A ton of organic waste processed by worms gives up to $600 \mathrm{~kg}$ of biohumus, which is a valuable organic fertilizer rich in nutrients and biologically active substances necessary for the production of environmentally friendly products.

Due to its chemical composition, worm biomass is a farm animals diet valuable fodder supplement. The chemical composition of the vermiculture biomass depends to a large extent on the nature of the nutrient medium in which the worms live. Metals concentration in the biomass of worms increases as the content of the metals in the nutrient medium increases (Merzlov \& Mashkin, 2015). 
Earthworms consume various organic soil fractions and may bioaccumulate some soil pollutants (Beyer et al., 1982; Ernst et al., 2008; Latif et al., 2013) The pollutants include trace minerals such as $\mathrm{ZnSO} 4 \cdot 7 \mathrm{H} 2 \mathrm{O}$. Sizmur et al. (2011) have shown in the research, that the presence of Lumbricus terrestris increases the bioavailability of metals in the soil. Similarly, other studies have shown bioaccumulation of metals $(\mathrm{Cu}, \mathrm{Pb}$ and $\mathrm{Zn})$ by $L$. terrestris in Canada urban soils (Kennette et al., 2002) and bioaccumulation of $\mathrm{Cu}$ and $\mathrm{Zn}$ by L. terrestris in the ponds with variable soils (Kizilkaya, 2004).

Centofanti et al. (2016) confirmed the ability of L. terrestris worms to bioaccumulate Zinc. Bioaccumulative factor for $\mathrm{Zn}$ was more than 4 .

Zinc is an important metal for bio-objects. The average quantitative content of zinc in the animals body is $0.0029 \%$ (of total weight) (Georgiyevskiy, 1970; Kidd et al., 1996). The metal activates more than 25 enzymes systems in the cell and is involved in cells distribution, regeneration and growth. The content of zinc in the body is related to the processes of bone tissue formation and growth. It also influences maintaining the skin in a satisfactory state, as well as hair growth and immunity. Metal biotic is involved in protein and nucleic exchanges, respiration cells, lipid metabolism and energy processes. Zinc is important for the development of ovules and fetuses. It is part of the insulin molecule and it activates testosterone, adrenaline and gonadotropic hormones. Being a part of the carbohydrazide, it participates in acid-alkaline balance maintaining. Zinc affects the function of triple hormones of the pituitary gland which provides sexual activity and the organism resistance (Fedorina et al., 2013).

Zinc affects the level of metabolite testosterone - dihydrotestosterone, the excess of the latter causes prostate hyperplasia. The metal is a necessary element for female organisms, as it is part of the structure of estrogen receptor and thus affects all processes related to estrogen (Paribok, 1974).

Zinc takes an active part in the thymus functioning through affecting the state of the immune system in the body. Due to the presence of retinolupporous protein, Zinc, in combination with vitamin A (and vitamin C), prevents immunodeficiencies by stimulating antibodies formation (Kononskiy, 2006).

The metal is involved in DNA and RNA synthesis, in antioxidation processes, in $\mathrm{CO}_{2}$ transportation and biomembranes stabilizing, in hematopoiesis and in functioning the internal secretion glands. Zinc plays an important role in transcription, in stabilizing the structures of the polysaccharide and biopolymers. It supports the physiological content of vitamin A in the blood and normal taste. The element is an integral part of a range of the following metalloenzymes: peptidase, dehydrogenase, transphosphorilase, urease, phosphatase, carbonic anhydrase, aldolase (Georgiyevskiy, 1970; Snitinskiy et al., 2002). Zinc is a component of the molecule necessary for the activation of pancreatic carboxypeptidase, protease, decarboxylase, dipeptidase, arginase, RNA and DNA polymerase, superoxide dismutase, and alcohol dehydrogenase. The metal is a part of the structure of the basic antioxidant enzyme - $(\mathrm{Zn}, \mathrm{Cu})-$ superoxide dismutase - and it induces the synthesis of proteins of cells, which confirms the antioxidant effect of this element.

Zinc is deposited in the liver, and then transported to other tissues and cells. In the animals body the metalbiotic is found predominantly in the form of complex compounds with biopolymers, including proteins (Paribok, 1974).

The exchange of zinc in the animals body is regulated by the thyroid gland. The deficiency of metal-biotic causes a delay in sexual development. Insignificant zinc deficiency results in RNA concentration and the synthesis of protein in the nerve cells decrease, it slows down the brain development, the impairment of the taste and smell receptors; the development of animals is slowed down; skin scaling, infertility manifestations, low amount of sperm is observed in the animals and wounds healing takes longer. A significant shortage of the metal causes bone growth slowing down; testicles hypoplasia and hypofunction manifestation; slow growth or dwarfness takes place, a cataract occurs.

Zinc excess in the body causes a negative effect on the functions of the heart and blood along with gastritis, lethargy, nausea, drowsiness, coordination disruption.

Cuprum, Cadmium, Plumbum are the functional antagonists of Zinc, especially against the backdrop of amino acids deficiency. In the form of chelating-forming complexes, the metal may act as a synergist of chromium (Georgiyevskiy, 1970; Avtsin et al., 1991).

Therefore, the purpose of our research was to study the influence of various doses of Zinc in the nutrient medium on worms reproduction, the dynamics of their body mass, and the accumulation of metal in the worms biomass.

\section{Material and methods}

The experiments were conducted in the vivarium of Bila Tserkva National Agrarian University. Red Californian worms hybrid was used as a biological object. For the experiment, 54 microboxes sized of $0.5 \mathrm{~m} \times 0.7 \mathrm{~m}$ were formed. $11.0 \mathrm{~kg}$ of nutrient medium (fermented cattle manure and straw of cereals) for was added to each microbox. The nutrient medium humidity was $65.0-67.0 \%$. The microboxes were divided into 6 groups with 9 units in each.

In the control group, the nutrient medium contained a natural zinc background. No additional metal was introduced. In the experimental group 1, $40 \mathrm{mg} / \mathrm{kg}$ of zinc was added to the nutrient medium in the microboxes at the expense of $\mathrm{ZnSO}_{4} \cdot 7 \mathrm{H}_{2} \mathrm{O}$ salt. $80 \mathrm{mg} / \mathrm{kg}$ of $\mathrm{Zinc}$ was added to the nutrient medium of the experimental group 2 . The nutrient medium from the experimental group 3 was enriched with Zinc at a rate of $160 \mathrm{mg} / \mathrm{kg}$. In the experimental groups 4 and 5,320 and $640 \mathrm{mg} / \mathrm{kg}$ of zinc were added to the nutrient medium in the microboxes, respectively. 80 mature worms was put into each box at the beginning of the experiment.

At the end of the experiment, which lasted 110 days, the number of worms in each microbox was counted, and the average samples of worms were taken to determine the content of zinc in their body. The selected worms were kept on dampened pieces of filter paper for 60 hours 
to release their gastrointestinal channel from coprolytes, the presence of which may result in the inaccuracies in the investigation of Zinc content. After the keeping, the worms were pre-dried, then ashed in a muffle furnace, gradually increasing the temperature to $450{ }^{\circ} \mathrm{C}$. The content of zinc in the worms biomass was determined by the atomic absorption spectrophotometry method using the Shimadzu AA-6650 equipment.

\section{Results and discussion}

By the end of the experiment, the average number of worms weighing $0.4-0.8 \mathrm{~g}$ in the control group was $134.9 \mathrm{pc}$ (Table 1). The number of adult worms increased by $26.5 \%(\mathrm{P} \leq 0.01)$ under vermiculture cultivation on a nutrient medium with an additional $40 \mathrm{mg} / \mathrm{kg}$ content of zinc. The stimulating effect of adding $80 \mathrm{mg} / \mathrm{kg}$ of zinc to the nutrient medium on the number and growth of vermiculture was found. The number of worms in the experimental group 2 was $57.2 \%$ higher than in the control.

Introducing $160 \mathrm{mg} / \mathrm{kg}$ of zinc into the nutrient medium (experimental group 3 microboxes) resulted in 1.9 times increased number of adult worms $(\mathrm{P} \leq 0.001)$. The application of $320 \mathrm{mg} / \mathrm{kg}$ of the studied metal-biotic brings about an increase in the number of adult worms in the experimental group 4 microboxes by $43.7 \%$ relative to the control. However, comparison of the number of individuals in the experimental group 3 microboxes reveals that the number of sexually active worms in the experimental group 4 was lower by $24.4 \%$.

\section{Table 1}

Number of worms and their mass in microboxes, depending on Zinc concentration in the nutrient medium, $\mathrm{n}=9$

\begin{tabular}{lcccc}
\hline Microboxes & \multicolumn{2}{c}{ Worms weighing $0,4-0,8 \mathrm{~g}$} & \multicolumn{2}{c}{ Worms weighing 0,01-0,39 $~$} \\
\cline { 2 - 5 } group & number, pc & mass, g & number, pc & mass, g \\
\hline Control & $134.9 \pm 3.94$ & $81.3 \pm 2.37$ & $130.0 \pm 3.59$ & $27.7 \pm 0.76$ \\
Experimental 1 & $170.7 \pm 8.38^{* *}$ & $103.8 \pm 5.10^{* *}$ & $144.1 \pm 5.30$ & $30.1 \pm 1.10$ \\
Experimental 2 & $212.0 \pm 7.31^{* * *}$ & $130.0 \pm 4.48^{* * *}$ & $163.8 \pm 5.25^{* *}$ & $34.7 \pm 1.11^{* *}$ \\
Experimental 3 & $256.6 \pm 7.49^{* * *}$ & $160.1 \pm 4.68^{* * *}$ & $199.2 \pm 5.47^{* * *}$ & $43.0 \pm 1.19^{* * *}$ \\
Experimental 4 & $193.9 \pm 5.74^{* * *}$ & $120.4 \pm 3.57^{* * *}$ & $172.6 \pm 5.50^{* *}$ & $37.6 \pm 1.20^{* * *}$ \\
Experimental 5 & $117.4 \pm 5.09^{*}$ & $70.8 \pm 3.08$ & $70.9 \pm 3.97^{* * *}$ & $14.5 \pm 0.81^{* * *}$ \\
\hline
\end{tabular}

Note: $*-\mathrm{P} \leq 0.05,{ }^{*}-\mathrm{P} \leq 0.01,{ }^{* * *}-\mathrm{P} \leq 0.001$

Growing worms on a nutrient medium with additional $640 \mathrm{mg} / \mathrm{kg}$ Zinc resulted in a decreased by $12.9 \%$ $(\mathrm{P} \leq 0.05)$ number of mature individuals as compared to the control.

Analysis of the mass of mature worms reveal that the weight of 134 worms was $81.3 \mathrm{~g}$ in the control group microboxes. The weight of experimental groups $1 \mathrm{mi}-$ croboxes microvermiculture was higher than that of the control by $26.5 \%(\mathrm{P} \leq 0.01)$. Introducing $80 \mathrm{mg} / \mathrm{kg}$ of zinc into the nutrient medium (experimental group 2 microboxes) results in $59.9 \%(\mathrm{P} \leq 0.001)$ worms mass increase relative to the control. It was found out that the cultivation of worms on a nutrient medium with the addition of metal-biotic in a dose of $160 \mathrm{mg} / \mathrm{kg}$ resulted in an increase in the weight of vermiculture by 1,97 times as compared with the data from the control group. Adding $320 \mathrm{mg} / \mathrm{kg}$ of zinc to nutrient medium was accompanied by $48.1 \%(\mathrm{P} \leq 0.001)$ increase in the mass of adult worms as compared with the control variant. This figure was $24.8 \%$ lower in the experimental group 4 as compared with the data of the experimental group 3 .

The negative influence of zinc at the dose of $640 \mathrm{mg} / \mathrm{kg}$ of nutrient medium on the worms mass increase was established. Use of that high dose of metal caused lower mass of vermiculture as compared with the control group and the experimental group 4 microboxes, respectively, by $12.9 \%$ and 1.7 times.

Consequently, the number and weight of mature worms depended on the content of zinc in the nutrient medium. The number and weight of worms was the highest for a dose of $160 \mathrm{mg} / \mathrm{kg}$ of nutrient medium. The dose of $640 \mathrm{mg} / \mathrm{kg}$ was toxic, which is confirmed by a decrease in the number and weight of vermiculture.
Also, the number and weight of non-mature (young) worms (aged up to 90 days and weight up to $0,39 \mathrm{~g}$ ) was recorded. In the variant without adding zinc (control), the number of non-pregnant worms was 130 pcs in a microbed. Introduction of $40 \mathrm{mg} / \mathrm{kg}$ of zinc resulted in $10.8 \%$ increase in the number of worms in the microbed relative to the control indicators. The use of $80 \mathrm{mg} / \mathrm{kg}$ of metal-biotic contributes to $26.0 \%$ increase in the number of individuals relative to the control. Increased number of worms has been established in the third experimental group microboxes as well. This value was the highest among the experimental groups and differed from the control by $53.2 \%$. The number of worms was $21.6 \%$ higher as compared to the experimental group $2 \mathrm{mi}-$ croboxes. An increase in the dose of zinc to $320 \mathrm{mg} / \mathrm{kg}$ was accompanied by a decrease in the number of impuberal worms in the microboxes by $13.4 \%$ as compared to the data obtained in the experimental group 3. However, the number of worms in group 3 remained higher by $32.8 \%$ as compared to the control.

The smallest number of worms was observed in microboxes of the experimental group 5. The value was 1.86 times lower than in the control and 2.4 times lower in the experimental group 4.

Thus, zinc in optimal doses stimulates the worms reproduction. Excessive increase of metal content in the nutrient medium negatively affects the increase in the number of worms in the vermiculture.

Researching into the number and weight of impuberal worms reveals that in the control group of microboxes 130 worms weighed $27.7 \mathrm{~g}$. The introduction of zinc in the amount of $40 \mathrm{mg} / \mathrm{kg}$ to the nutrient medium (experi- 
mental group 1 microboxes) resulted in an increase in the vermiculture mass by $8.7 \%$ relative to the control.

Applying the metal in the amount of $80 \mathrm{mg} / \mathrm{kg}$, the mass of worms increases by $25.3 \%(\mathrm{P} \leq 0.01)$ relative to the control and by $15.3 \%$ relative to the value of the experimental group 1. Zinc in the dose of $160 \mathrm{mg} / \mathrm{kg}$ contributed to an increase in the worms mass by $55.2 \%$ $(\mathrm{P} \leq 0.001)$ relative to the control index and by $23.9 \%$ relative to the data of experimental group 2 . Worms cultivation on a nutrient medium with additional introducing of the metal-biotic in the amount of $320 \mathrm{mg} / \mathrm{kg}$ resulted in a decrease in the mass of impuberal worms by $12.6 \%$ relative to the value of the experimental group $3 \mathrm{mi}$ croboxes. The worms mass in the experimental group 4was higher by $35.7 \%(\mathrm{P} \leq 0.001)$ relative to the control.

Introduction of zinc at a dose of $640 \mathrm{mg} / \mathrm{kg}$ of the nutrient medium resulted in decreased weight of impuberal worms in the control and the experimental group 4, respectively, by 1.9 and 2.6 times.

Thus, different doses of zinc have various effect on the mass of impuberal worms as well. In the control, the average weight of young worms was 0.213 . Introduction of $160 \mathrm{mg} / \mathrm{kg}$ of zinc resulted in $1.4 \%$ higher average weight of worms than that of the control. The highest dose of metal caused a decrease in the average weight of impuberal worms relative to this value in the control group and in the experimental group 3, respectively, by $4.2 \%$ and $5.6 \%$.

The results of the determination of zinc content in the the red Californian worm hybrid dry matter are presented in Table 2. In the dry matter of the control group worms grown on the nutrient medium without addition of zinc, the metal content was $104.4 \mathrm{mg} / \mathrm{kg}$.

\section{Table 2}

The content of Zinc in the dry biomass of the red Californian worms hybrid, $\mathrm{n}=9$

\begin{tabular}{lc}
\hline Microboxes group & Zink mass concentration, $\mathrm{mg} / \mathrm{kg}$ \\
\hline Control & $104.4 \pm 3.70$ \\
Experimental 1 & $125.7 \pm 5.84^{*}$ \\
Experimental 2 & $137.5 \pm 9.53^{*}$ \\
Experimental 3 & $156.6 \pm 9.29^{* *}$ \\
Experimental 4 & $283.1 \pm 11.02^{* * *}$ \\
Experimental 5 & $316.3 \pm 10.31^{* * *}$ \\
\hline
\end{tabular}

In the dry mass of worms of the experimental group 1 microboxes the content of zinc was higher than that in the control by $20.4 \%(\mathrm{P} \leq 0.05)$. Growing worms on a nutrient medium with additional introduction of Zink in the amount of $80 \mathrm{mg} / \mathrm{kg}$, resulted in $31.7 \%(\mathrm{P} \leq 0.05)$ higher accumulation of this metal in a dry matter of the vermiculture than in the control. An increase in the content of zinc in the dry matter of worms of the experimental group 3 microboxes has been established. The difference with the control was $50.0 \%(\mathrm{P} \leq 0.01)$. Comparison of the metal content in the experimental group 3 worms dry matter to the value for vermiculture biomass of the experimental groups 1 and 2 reveals that the concentration of zinc was higher, respectively, by $24.5 \%$ and $13.8 \%$.

The content of zinc in the dry mass of vermiculture of the experimental group 4 was higher than in the control by $2.7(\mathrm{P} \leq 0.001)$ times. The highest metal content was in the dry matter of the worms grown in a nutrient medium added $640 \mathrm{mg} / \mathrm{kg}$ of zinc. The metal concentration in the dry matter of vermiculture was $316.3 \mathrm{mg} / \mathrm{kg}$, which exceeds the control data by 3.0 times.

\section{Conclusion}

The research confirms the ability of metals to accumulate in the body of worms on an example of zinc. The worms number and mass increase depends on zinc concentration in the nutrient medium. The stimulating effect of metal-biotic on the worms reproduction exhibits at the doses of $80-160 \mathrm{mg} / \mathrm{kg}$ of nutrient medium. Adding zinc at a dose of $640 \mathrm{mg} / \mathrm{kg}$ of the nutrient medium caused toxic effect of the metal on the worms, which resulted in a decrease in the number of impuberal worms by $12.9 \%$ $(\mathrm{P} \leq 0.05)$ as compared with the control $(134.9 \pm 3.94)$.

We have established a direct relation between zinc content in the nutrient medium and its content in the dry matter of vermiculture. Consequently, the content of zinc in the dry matter of the worms of the control group was $104.4 \mathrm{mg} / \mathrm{kg}$ whereas in all the experimental groups this value was higher with the highest in the experimental group $5(316.3 \mathrm{mg} / \mathrm{kg})$, which exceeds the control by 3.0 times.

\section{References}

Avtsin, A.P., Zhavoronkov, A.A., Rish, M.A. \& Strochkova, L.S. (1991). Mikroelementozy cheloveka, (etiologiya, klassifikatsiya, organopatologiya), 124187 (in Russian).

Beyer, W.N., Chaney, R.L., \& Mulhern, M. (1982). Heavy metal concentrations in earthworms from soil amended with sewage sludge. Journal of Environmental Quality, 11(3), 381-385. doi: 10.2134/ jeq1982.00472425001100030012x.

Centofanti, T., Chaney, R.L., Beyer, N.W., McConnell, L.L., Davis, A.P., \& Jackson, D. (2016). Assesstment of trace element accumulation by earthworms in an orchard soil remediation study using soil amendments. Water Air Soil Pollut, 227, 350. doi: 10.1007/s11270016-3055-0.

Das, A.K., \& Dach, M.C. (1989). Earthworms meal as a protein concentrate for Japanese quails. Ind. J. Poultry Science, 24(2), 137-138.

Das, A.K., \& Dach, M.C. (1990). Earthworms meal as a protein concetrate for broilers. Indonesion J. of Tropical Agriculture, 67(4), 342-344.

Ernst, G., Zimmermann, S., Christie, P., \& Frey, B. (2008). Mercury, cadmium and lead concentrations in different ecophysiological groups of earthworms in forest soils. Environmental Pollution, 156(3), 13041313. doi: 10.1016/j.envpol.2008.03.002.

Fedorina, T.A., Nadeyev, V.P., \& Chabayev, M.G. (2013). Gistologicheskaya struktura vnutrennikh organov pri skarmlivanii khelatov medi, zheleza, margantsa, tsinka i selena Izvestiya Nizhnevolzhskogo agrouniversitetskogo kompleksa: nauka i vyssheye professionalnoye obrazovaniye. Volgograd, 2(30), 125-131 (in Russian). 
Feruchchi, K. (1992). Domashnye hospodarstvo z rozvedennya doshchovykh cherv'yakiv $\mathrm{v}$ ekolohichnykh yashchykakh. Tez. dop. 2-ho konhresu "Biokonversiya orhan. vidkhodiv nar. hosp-va ta okhorona navkolyshnoho seredovyshcha". Ivano-Frankivsk, 136-137 (in Ukrainian).

Georgiyevskiy, V.I. (1970). Mineralnoye pitaniye selskokhozyaystvennoy ptitsy. 84-134 (in Russian).

Hasanuzzaman, A.F.Md., Hossian, Sk.Z., \& Das, M. (2010). Nutritional potentiality of earthworm (Perionyx excavatus) for substituting fishmeal used in local feed company in Bangladesh. Mesopot. J. Mar. Sci., 25(2), 134-139. https://iasj.net/iasj?func=fulltext\&aId=33985.

Kennette, D., Hendershot, W., Tomlin, A., \& Sauvé, S. (2002). Uptake of trace metals by the earthworm Lumbricus terrestris L. in urban contaminated soils. Applied Soil Ecology, 19, 191-198. https://elibrary.ru/item.asp?id=1075161.

Kholodova, U.D., Povhan, M. F., \& Morozova, R.P. (1992). Fabrics worms Eisenia foetida as a raw material source for the production of pharmaceuticals. Bioconversion of organic waste of the economy and the environment. Ivano-Frankivsk, 138-139.

Kholodova, U.D., Morozova, R.P., Bezpalko, A.S., \& Nikolaenko, I.A. (1994). The source of biologically active substances. Chemicals in the fields of agriculture, 4, 18-19.

Kidd, M.T., Ferket, P.R., \& Qureshi, M.A. (1996). Zinc metabolism with special reference to its role in immunity. World's Poultry Science J., 52(3), 309-324. doi: 10.1079/WPS19960022.

Kizilkaya, R. (2004). Cu and $\mathrm{Zn}$ accumulation in earthworm Lumbricus terrestris $L$. in sewage sludge amended soil and fractions of $\mathrm{Cu}$ and $\mathrm{Zn}$ in casts and surrounding soil. Ecological Engineering, 22(2), 141151. doi: 10.1016/j.ecoleng.2004.04.002.

Kononskiy, O.I. (2006). Biokhimiya tvaryn. K.: Vishcha shkola (in Ukrainian).

Kostecka, J. \& Pączka, G. (2006). Possible use of earthworm Eisenia foetida (Sav.) biomass for breeding aquarium fish. European Journal of Soil Biology, 42(1), 231-233. doi: 10.1016/j.ejsobi.2006.07.029.

Latif, R., Malek, M., \& Mirmonsef, H. (2013). Cadmium and lead accumulation in three endogeic earthworm species. Bulletin of Environmental Contamination and Toxycology, 90(4), 456-459. doi: 10.1007/s00128012-0941-z.

Mason, W.T., Rottmann, R.W., \& Dequine, J.F. (1992). Culture of earthworms for bait or fish food. Florida Cooperative Extension Service, Institute of Food and Agricultural Sciences, University of Florida, 1053, 14.

Melnyk, I.A. (1991). Doshchovi chervyaky na sluzhbi silskoho hospodarstva. Kormovi kultury, 4, 30 (in Ukrainian).

Merzlov, S.V., \& Mashkin, Yu.O. (2015). Vmist Ferumu ta Magniju u biomasi vermykul'tury v zalezhnosti vid skladu substratu Mizhnarodna naukovo-praktychna konferencija 'Rozvytok nacional'noi' ekonomiky: teorija i praktyka", Chastyna 1, Ivano-Frankivs'k, 1819 (in Ukrainian).

Paribok, T.A. (1974). O roli tsinka v metabolizme. Biologicheskaya rol mikroelementov i ikh primeneniye $\mathrm{v}$ selskom khozyaystve i meditsine, 306-319 (in Russian).

Pernak, B.S. (1995). Pererobka miskykh vidkhodiv v orhanichne dobryvo - biohumus. Tez. dop. Mizhnar. nauk.-tekhn. konf. "Biotekh -95". Dnipropetrovsk, 18-19 (in Ukrainian).

Sizmur, T., Palumbo-Roe, B., Watts, M.J., \& Hodson, M.E. (2011). Impact of the earthworm Lumbricus terrestris (L.) on $\mathrm{As}, \mathrm{Cu}, \mathrm{Pb}$ and $\mathrm{Zn}$ mobility and speciation in contaminated soils. Environmental Pollution, 159(3), 742-748. doi: 10.1016/j.envpol.2010.11.033.

Snitinskiy, V.V., Glozhik, I.Z., \& Danchuk, V.V. (2002). Biologichni aspekty vilnoradykalnogo okyslennya $\mathrm{u}$ silskogospodarskykh tvaryn u zvyazku $\mathrm{z}$ fíziologichnym stanom i vmístom tsinku u ratsioni. Fiziol. Zhurnal, 48(2), 191-192 (in Ukrainian).

Sulzberger, R. (1998). Kompost und wurmhumus. München. 